\title{
The effects of condensed tannins from Desmodium intortum and Calliandra calothyrsus on protein and carbohydrate digestion in sheep and goats
}

\author{
BY R. A. PEREZ-MALDONADO AND B. W. NORTON* \\ Department of Agriculture, University of Queensland, Brisbane, Queensland 4072, Australia
}

(Received 14 March 1995 - Revised 30 October 1995 - Accepted 10 January 1996)

\begin{abstract}
A factorial experiment was conducted to study the effects of condensed tannins (CT) from the tropical legumes Desmodium intortum and Calliandra calothyrsus on the digestion and utilization of protein and carbohydrate in sheep and goats. CT-free Centrosema pubescens was also fed for comparison with the CT legumes, and each legume was included $(300 \mathrm{~g} / \mathrm{kg} \mathrm{DM})$ in a basal diet of pangola grass (Digitaria decumbens). Pangola grass alone was used as a control diet. There were no significant $(P>0.05)$ differences between sheep and goats for the efficiency of digestion of $N(0.574, \mathrm{SE} 0.013)$, organic matter (OM; 0.519, SE 0.010), neutral-detergent fibre (NDF; 0.524, SE 0.011) and acid-detergent fibre (ADF; 0.407, SE 0.016). Diets containing desmodium and calliandra were digested less well in the rumen (64 and $62 \%$ of total OM digested) when compared with the pangola and centrosema diets ( 74 and $73 \%$ of total OM digested in rumen). There was an apparent net gain of $30 \%$ in ADF across the digestive tract of sheep and goats given calliandra, and this gain was ascribed to the formation of 'artifact' fibre as a result of fibre-tannin interaction. Overall, inclusion of legume at $300 \mathrm{~g} / \mathrm{kg}$ in the diet significantly increased ( $P$ $<0.05)$ the concentration of acetic acid and decreased butyric acid concentration in the rumen fluid of sheep and goats. Significantly higher proportions of dietary $\mathbf{N}$ apparently reached the abomasum of animals given the diets containing desmodium $(50 \%)$ and calliandra $(56 \%)$ when compared with animals given the centrosema and pangola diets $(35 \%)$. Sheep and goats given the CT diets also had higher excretions of faecal $N$. This increment of faecal $N(14 \%)$ did not affect post-rumen $N$ digestion $(P>$ 0.05) since animals given $C T$ diets absorbed more $N(19 \%)$ per $\mathrm{kg}$ total $\mathrm{OM}$ digested than those given the control diets. It was concluded that whilst the low levels of CT provided in desmodium $(1.0 \%)$ and calliandra (2.3\%) diets protected dietary protein from degradation in the rumen, there were no overall beneficial or detrimental effects of CT in these diets for sheep or goats. A method was developed to categorize CT into fractions representative of their forms (free, protein-bound, and fibre-bound) during the digestion process. A quantitative model of CT metabolism during passage through the digestive tract was developed from the measured exchanges of CT between free, protein-bound and fibre-bound pools in the rumen and lower digestive tract. CT interchange mainly occurred in the reticulo-rumen of both animal species. Desmodium and calliandra free CT showed net losses of 68 and $78 \%$ in the rumen respectively and 57 and $68 \%$ of the fibre-bound $\mathrm{CT}$ was lost in the same site for sheep and goats respectively. However, protein-bound $\mathrm{CT}$ increased across the rumen by 73 and $56 \%$ for both animal species. Post-rumen losses of the total CT abomasal flow were 86 and $83 \%$ (free CT) for sheep and goats respectively, 70 and $66 \%$ (protein-bound CT), whilst $28 \%$ loss of fibre-bound CT occurred in sheep and goats respectively.
\end{abstract}

Condensed tannins: Protein: Carbohydrate: Sheep: Goats

Condensed tannins (CT) and hydrolysable tannins (HT) are polyphenolic compounds found as secondary compounds in some leguminous plants. HT are usually toxic to animals, while low concentrations of CT in the diet appear to be beneficial. When Lotus

* For reprints. 
corniculatus (15 g CT $/ \mathrm{kg} \mathrm{DM})$ was fed to sheep, protein degradation in the rumen was reduced, and protein flow to the small intestine increased without affecting overall organic matter (OM) digestion (Waghorn et al. 1987; Waghorn, 1990). Low concentrations of CT $(20 \mathrm{~g} / \mathrm{kg} \mathrm{DM})$ have also been shown to reduce carcass fatness in growing lambs (Purchas \& Keogh, 1984). These beneficial effects of CT are attributed to the formation of stable CT-protein complexes in the rumen which reduces microbial degradation of plant proteins, and subsequent dissociation of these complexes in the lower tract releases protein for intestinal digestion and absorption (Jones \& Mangan, 1977). However, when levels of CT in L. pedunculatus are increased above $60 \mathrm{~g} / \mathrm{kg}$ DM, voluntary feed intake (VFI) and diet digestibility in sheep are decreased (Barry \& Duncan, 1984; Waghorn et al. 1987).

There is a need to define the optimum concentration and types of CT in different feed sources consistent with reduced protein degradation in the rumen, increased post-rumen absorption of non- $\mathrm{NH}_{3}-\mathrm{N}$ (NAN) and the maintenance of high VFI. It also appears that CT may be metabolized differently in different ruminants. There is evidence that goats may be less susceptible than sheep to the detrimental effects of CT, and microbial tanninase enzymes in the rumen are thought to be responsible.

The objective of the present study was to investigate the effect of CT from a tropical forage legume (Desmodium intortum) and a fodder tree legume (Calliandra calothyrsus) on the digestion and utilization of feed protein and carbohydrate in sheep and goats. Measurements of CT loss across the rumen and in the post-rumen tract were also determined in order to develop a descriptive model of the metabolism of tannins in ruminants.

\section{MATERIALS AND METHODS \\ Preparation of forage diets}

Pangola grass (Digitaria decumbens) and the legumes Desmodium intortum (cv. greenleaf) and Centrosema pubescens were grown at Mount Cotton University Research Farm located in south-east Queensland. The legumes were grown over the summer period (NovemberMarch) and were harvested and air-dried in an air-flow ventilated bunker. Dry hay was then chopped ( $30-80 \mathrm{~mm}$ ) and stored in hessian bags. Edible leaf (leaf and stem $<2 \mathrm{~mm}$ ) was hand stripped from established Calliandra calothyrsus trees growing at Mount Cotton University Farm and air-dried before being fed to animals.

\section{Animals and their diets}

Four castrated male Border Leicester $\times$ Merino wethers, 2 years old, mean live weight $30 \cdot 2$ (SE 0.95$) \mathrm{kg}$, and four castrated male Australian cashmere goats, 6-8 months old, mean live weight 18.5 (SE 1.77) kg, were used as experimental animals. Sheep and goats were each fitted with a 'Jarret' cannula in the rumen and a ' $T$ '-piece cannula in the abomasum, 5 weeks before commencing the experiment. Sheep and goats received a mixed ration of pangola hay and lucerne (Medicago sativa) hay for about $25 \mathrm{~d}$ before the experimental period. After this, all the animals were drenched for internal parasites (Ivomec, Merck Sharp and Dohme, Australia Ltd, Granville, NSW, Australia) at fortnightly intervals. The animals were then transferred to a temperature-controlled animal house $\left(22^{\circ}, 20 \%\right.$ humidity) located at the University campus. Throughout the experiment, sheep and goats were individually held in metabolism cages with free access to water and fed hourly from automatic overhead belt feeders.

In the animal house 1 week of adaptation was allowed during which pangola grass hay $(500 \mathrm{~g} / \mathrm{d})$ was provided. After 1 week all animals were weighed and offered the experimental diets at a rate of $30 \mathrm{~g} \mathrm{DM} / \mathrm{kg}^{0 \cdot 9}$ per d (approximately $90 \%$ ad libitum intake) for the duration of each experimental period. Sheep and goats were offered one of the following 
Table 1. Chemical composition $(\mathrm{g} / \mathrm{kg} \mathrm{DM})$ of components and whole diets ( $300 \mathrm{~g}$ legume $/ \mathrm{kg}$ $D M$ ) containing pangola-grass (Digitaria decumbens) alone, pangola and centrosema (Centrosema pubescens), pangola and desmodium (Desmodium intortum) and pangola and calliandra (Calliandra calothyrsus) fed to sheep and goats

\begin{tabular}{|c|c|c|c|c|c|c|c|}
\hline & \multirow[b]{2}{*}{ Pangola } & \multicolumn{2}{|c|}{ Centrosema } & \multicolumn{2}{|c|}{ Desmodium } & \multicolumn{2}{|c|}{ Calliandra } \\
\hline & & Alone & $\begin{array}{l}\text { Whole } \\
\text { diet }\end{array}$ & Alone & $\begin{array}{c}\text { Whole } \\
\text { diet }\end{array}$ & Alone & $\begin{array}{c}\text { Whole } \\
\text { diet }\end{array}$ \\
\hline $\begin{array}{l}\text { Organic matter } \\
\text { Nitrogen }\end{array}$ & $\begin{array}{l}956 \\
14.4\end{array}$ & $\begin{array}{l}948 \\
26.6\end{array}$ & $\begin{array}{l}954 \\
18 \cdot 1\end{array}$ & $\begin{array}{l}934 \\
18 \cdot 8\end{array}$ & $\begin{array}{l}949 \\
18 \cdot 8\end{array}$ & $\begin{array}{l}951 \\
30 \cdot 2\end{array}$ & $\begin{array}{l}954 \\
19 \cdot 1\end{array}$ \\
\hline $\begin{array}{l}\text { Neutral-detergent fibre } \\
\text { Acid-detergent fibre } \\
\text { Condensed tannins }\end{array}$ & $\begin{array}{l}647 \\
312\end{array}$ & $\begin{array}{l}595 \\
391\end{array}$ & $\begin{array}{l}631 \\
334\end{array}$ & $\begin{array}{l}630 \\
504\end{array}$ & $\begin{array}{l}630 \\
504\end{array}$ & $\begin{array}{l}372 \\
230\end{array}$ & $\begin{array}{l}565 \\
287\end{array}$ \\
\hline $\begin{array}{l}\text { Free (butanol-HCl) } \\
\text { (vanillin-HCl) } \\
\text { Protein-bound } \\
\text { Fibre-bound } \\
\text { Total condensed tannins }\end{array}$ & $\begin{array}{l}\text { ND } \\
\text { ND } \\
\text { ND } \\
\text { ND }\end{array}$ & $\begin{array}{l}\text { ND } \\
\text { ND } \\
\text { ND } \\
\text { ND }\end{array}$ & $\begin{array}{l}\text { ND } \\
\text { ND } \\
\text { ND } \\
\text { ND }\end{array}$ & $\begin{array}{r}8 \cdot 9 \\
15 \cdot 9 \\
13 \cdot 4 \\
9 \cdot 5 \\
31 \cdot 8\end{array}$ & $\begin{array}{l}2 \cdot 7 \\
4 \cdot 8 \\
4 \cdot 0 \\
2 \cdot 9 \\
9 \cdot 5\end{array}$ & $\begin{array}{r}47 \cdot 1 \\
109 \cdot 3 \\
12 \cdot 2 \\
15 \cdot 7 \\
75 \cdot 0\end{array}$ & $\begin{array}{r}14 \cdot 1 \\
32 \cdot 8 \\
3 \cdot 7 \\
4 \cdot 7 \\
22 \cdot 5\end{array}$ \\
\hline
\end{tabular}

ND, not detected.

diets: (1) pangola grass hay fed alone (pangola); (2) pangola grass hay (700 g/kg) mixed with $C$. pubescens hay $(300 \mathrm{~g} / \mathrm{kg}$ ) (centrosema); (3) pangola grass hay $(700 \mathrm{~g} / \mathrm{kg}) \mathrm{mixed}$ with $D$. intortum hay $(300 \mathrm{~g} / \mathrm{kg}$ ) (desmodium) and (4) pangola grass hay $(700 \mathrm{~g} / \mathrm{kg})$ mixed with $C$. callothyrsus hay $(300 \mathrm{~g} / \mathrm{kg}$ ) (calliandra). Only desmodium and calliandra contain CT. The composition of the components and whole diets is shown in Table 1. At the beginning of each period when diets were changed, live weights were again recorded and feed intakes adjusted accordingly. Metabolic body size (body weight $(\mathbf{k g})^{0.9}$ ) was used to provide equivalent feed allocations to the sheep and goats (Graham, 1972; Norton et al. 1994). All feed offered was consumed.

\section{Experimental design and statistical analyses}

The four treatment diets were offered in four periods in a Latin square design. The diets were randomly allocated to each group of sheep and goats (four animals per group). Each experimental period lasted $28 \mathrm{~d}$. The differences between treatments were analysed using a complete randomized Latin square analysis. ANOVA was performed using SAS (SAS/STAT version 6, 1987; SAS Institute Inc., Cary, NC, USA).

\section{Measurements and sampling}

The experiment was conducted over four periods of $28 \mathrm{~d}$ each. The first $14 \mathrm{~d}$ was an adaptation period and was followed by $7 \mathrm{~d}$ for $\mathrm{N}$ balance and feed digestibility determination. The next $7 \mathrm{~d}$ were allowed for sampling of rumen and abomasal digesta. Digesta and dietary constituent flows from the abomasum were calculated from the concentrations of ${ }^{51} \mathrm{Cr}$-EDTA and ${ }^{103} \mathrm{Ru}$-phenanthroline $\left({ }^{103} \mathrm{Ru}-\mathrm{P}\right)$ in whole digesta and digesta filtrate by the double marker method described by Faichney $(1975 a) .{ }^{35} \mathrm{~S}$-labelled $\mathrm{Na}_{2} \mathrm{SO}_{4}$ was also used for the measurement of microbial- $\mathrm{N}$ and, by difference, undegraded feed protein in digesta. Digestibility and $\mathrm{N}$ balance were measured from day 15 to day 21 (7 d) in metabolism cages equipped with sieve collectors that separated urine from faeces. Urine samples were collected through glass wool into a plastic bucket (4 litres) which contained $40 \mathrm{ml}$ glacial acetic acid. Faeces were collected in plastic bags attached to the 
sieve collector. Urine and faeces collections from each animal were weighed every second day and sub-sampled $(10 \%)$, pooled and stored at $-20^{\circ}$ for later analysis.

\section{Marker infusion and digesta flow measurements}

Digesta flow at the abomasum was determined from day 22 to day 28 (final $7 \mathrm{~d}$ ) from an intra-rumen infusion (300 ml/animal per d) containing ${ }^{51} \mathrm{Cr}$-EDTA $(1850 \mathrm{kBq})$ as a marker of the digesta fluid phase (Downes \& McDonald, 1964), ${ }^{103} \mathrm{Ru}-\mathrm{P}(370 \mathrm{kBq})$ as a marker of the digesta solids (Tan et al. 1971) and $\mathrm{Na}_{2}{ }^{35} \mathrm{SO}_{4}(1850 \mathrm{kBq})$ as a marker of microbial protein (Elliott \& Armstrong, 1982). Six samples of abomasal digesta (approximately $300 \mathrm{~g}$ /animal) were collected every $8 \mathrm{~h}$ over a $48 \mathrm{~h}$ period commencing on day 3 from the $5 \mathrm{~d}$ infusion period (days 24 and 25 ). Samples of strained rumen fluid $(3 \mathrm{ml})$ were taken every $8 \mathrm{~h}$ during the same period. Samples of rumen contents were collected 4, 8, 12, 20, 28,36 and $48 \mathrm{~h}$ after the intra-rumen infusion was terminated. Individual abomasal samples from each animal were mixed and bulked over $24 \mathrm{~h}$ collection, thereby providing two samples from each animal for analysis. The bulked samples of abomasal digesta were designated as bulked whole digesta (WD). This WD was then divided into two portions (A and $B)$. Before freeze-drying portion $A$, a representative sample $(80 \mathrm{ml})$ of this WD was taken and mixed with $40 \mathrm{~g} / 1$ Cab-osil ( $\mathrm{SiO}_{2}$; Fluka Chemie $\mathrm{AG}, \mathrm{CH}-9470$ Buchs, Switzerland) and assayed for ${ }^{51} \mathrm{Cr}$ and ${ }^{103} \mathrm{Ru}$ activity. At the same time, $200 \mathrm{ml}$ of portion $A$ WD was also used for the determinations of the specific activity of cysteine ${ }^{35} \mathrm{~S}$ and for analysis of all constituents (DM, OM, N, neutral-detergent fibre (NDF), acid-detergent fibre (ADF), and total tannins (free, protein-bound and fibre-bound). Portion B ( 0.66 of the total bulked WD) was strained through a double cheesecloth (Faichney, 1980) and the filtrate was subdivided into two parts (C and D). Filtrate $C$ was used for ${ }^{51} \mathrm{Cr}$ and ${ }^{103} \mathrm{Ru}$ determination and the remaining fraction was freeze-dried and analysed as described for WD portion A. Filtrate D was lightly centrifuged ( $500 \mathrm{~g}$ for $10 \mathrm{~min}$ ), and the supernatant fraction was re-centrifuged at $20000 \mathrm{~g}$ for $20 \mathrm{~min}$. This supernatant fraction was collected for $\mathrm{NH}_{3}$ determination and the residue (microbial fraction) was freeze-dried and subsequently analysed for cysteine ${ }^{35} \mathrm{~S}$. Every microbial fraction was microscopically examined to ensure that it was not contaminated with plant material.

\section{Analytical methods}

The content of DM in feed, faeces and digesta was determined by drying the material at $70^{\circ}$ for $48 \mathrm{~h}$, and this was followed by ash determination (incineration for $4 \mathrm{~h}$ at $600^{\circ}$ ). Total $\mathrm{N}$ in feed, faecal samples, abomasal WD and filtrate and urine was analysed by combustion in a N analyser system (LECO FP-428, St Joseph, MI, USA). ADF and NDF fractions were determined in feed, faeces and WD by the method of Goering \& Van Soest (1970).

Rumen and abomasal ammonia. Concentrations of $\mathrm{NH}_{3}$ in rumen and abomasal contents were determined by steam distillation followed by titration with $0.01 \mathrm{M}-\mathrm{HCl}$ while concentrations of individual VFA in rumen samples were determined by GLC using a gas chromatograph (Hewlett Packard 8530A, Hewlett Packard, Palo Alto, CA) with a terminal (HP 18850A) following deproteinization with metaphosphoric acid $(250 \mathrm{ml} / 1)$ isocaproic acid $(12 \mathrm{mg} / \mathrm{ml})(4: 1, \mathrm{v} / \mathrm{v})$. A column of teflon tubing $(180 \mathrm{~mm} \times 3 \mathrm{~mm}$ (Cat. no. 31431 Analytical Instruments, Scarborough, Queensland, Australia) packed with Chromosorb 101 was used with $\mathrm{N}_{2}(60 \mathrm{psi}, 40 \mathrm{ml} / \mathrm{min})$ as the carrier gas. ${ }^{51} \mathrm{Cr}$-EDTA and ${ }^{103} \mathrm{Ru}$ activities were determined in a Hewlett Packard Gamma counter (Model 5212, Packard Instrument Co. Downers Grove, IL, USA). Rumen fluid volume and outflow rate from the rumen were calculated from the disappearance of ${ }^{51} \mathrm{Cr}$ after the continuous infusion of 
${ }^{51}$ Cr-EDTA solution was stopped (Faichney, 1975a). The proportions of cystine of microbial origin in the WD supernatant fraction and abomasal microbial fraction were determined by the method of Elliott \& Armstrong (1982), ${ }^{35} \mathrm{~S}$ activity was determined in a Hewlett Packard scintillation counter (Tri-Carb, model 4430).

Condensed tannin analysis. CT fractions (free, protein-bound and fibre-bound) were estimated in feed, urine (as total phenolics), faeces, rumen digesta, and abomasal WD samples obtained from animals given $D$. intortum and $C$. calothyrsus. CT was not detected in samples from sheep consuming the other diets. The method of Terrill et al. (1992) was used to isolate the various tannin fractions, with the following modifications (PerezMaldonado, 1994). Free-tannin estimation: ethyl acetate was used as final extractant to remove any contaminating small phenolic compounds. Protein-bound tannin: the method of Terrill et al. (1992) used a solution of SDS (10 ml/1) and 2-mercaptoethanol (50 ml/1) buffered (Tris buffered (Tris buffer) to $\mathrm{pH} 8$ with HCl. This solution does not effectively release protein-bound tannins from digesta samples (Terrill et al. 1994); the presence of $\mathrm{HCl}$ was considered likely to lead to an underestimation of tannins and the volatility of a $50 \mathrm{ml} / 1$ solution of mercaptoethanol is too dangerous for routine laboratory use. The replacement of $10 \mathrm{~mm}$ Tris buffer with $50 \mathrm{ml} / 1$ tri-ethanolamine and decreasing 2mercaptoethanol from 50 to $10 \mathrm{ml} / 1$, increased the $\mathrm{pH}$ of the solution to 10 , and facilitated the release of protein-bound tannins from digesta samples. Fibre-bound tannins were isolated and assayed in methanol rather than water.

Free tannin. These analyses were made on freeze-dried ground feed, feed refusals, WD and faecal samples. Samples $(300 \mathrm{mg}$ ) were weighed into screw-capped glass tubes, and $20 \mathrm{ml}$ acetone $\left(700 \mathrm{ml} / \mathrm{l}\right.$, with $1 \mathrm{~g}$ ascorbic acid/l) was added, de-gassed with $\mathrm{N}_{2}$ and mixed on a rotary mixing wheel for $150 \mathrm{~min}$ (three times). The supernatant fraction was decanted after centrifugation ( $3000 \mathrm{rev} . / \mathrm{min}, 10 \mathrm{~min}$ ) and acetone removed by rotary evaporation $\left(40^{\circ}\right)$ leaving a final volume of approximately $7 \mathrm{ml}$. This solution was then transferred to a $20 \mathrm{ml}$ glass vial, using diethyl ether to rinse the round-bottomed flask. This extracted solution was then mixed thoroughly with equal volumes of diethyl ether, shaken vigorously, causing phase separation in the solution after a few minutes. The upper solvent layer containing the pigments was discarded by vacuum aspiration, and this step was repeated three times. The water-soluble free tannins remained in the lower water layer to which was added an equal volume of ethyl acetate to eliminate small phenolic compounds. After eliminating the ethyl acetate by vacuum aspiration, rotary evaporation was then repeated to eliminate any traces of solvent and also to reduce the total volume to approximately $5 \mathrm{ml}$. This extract was then made to $10 \mathrm{ml}$ with methanol $(800 \mathrm{ml} / 1)$. This final extract, representing the free tannin fraction, was stored $\left(4^{\circ}\right)$ for later analysis.

Protein-bound tannin. The residues that remained from the previous extraction were dried for $12 \mathrm{~h}$ at $60^{\circ}$. A $5 \mathrm{ml}$ portion of SDS solution (SDS $(10 \mathrm{~g} / \mathrm{l})$, triethanolamine $(50 \mathrm{~g} / 1)$, and 2-mercaptoethanol $(10 \mathrm{~g} / 1))$ was added to those residues, then the tubes were capped tightly, mixed and placed in a water bath at $100^{\circ}$ for $75 \mathrm{~min}$. (Faecal sample residues, which have bile pigments, were extracted twice with diethyl ether for $20 \mathrm{~min}$ before carrying out the next step.) After cooling to room temperature, tubes were vortexmixed and centrifuged (3000 rev/min, $10 \mathrm{~min}$ ) to obtain a supernatant fraction which was representative of the protein-bound tannin fraction within the sample.

Fibre-bound tannin. The residue from the SDS extraction was washed and centrifuged twice with $5 \mathrm{ml}$ methanol $(800 \mathrm{ml} / 1)$ and once with butanol to eliminate any traces of SDS. The tannin analysis in these residues represents the fibre-bound tannin fraction of the sample.

Tannin assay. Tannin assays for the three fractions (free, protein-bound and fibre-bound CT) were performed with butanol $-\mathrm{HCl}$ (Bate-Smith, 1981) using purified CT from $D$. 
intortum as reference standard. Initially the vanillin- $\mathrm{HCl}$ method was also used for total $\mathrm{CT}$ determination, but positive reactions were only obtained in the free-tannin fraction. Subsequently butanol- $\mathrm{HCl}$ was adopted as the preferred method for CT determination in feed, digesta and excreta. Since no CT could be detected in urine samples by butanol- $\mathrm{HCl}$, total phenolic content was determined by the method of Singleton \& Rossi (1965) using purified CT from $D$. intortum as reference standard.

\section{RESULTS}

\section{Conceptual model of condensed tannins exchange during digestion}

Tannin exchanges between free, protein-bound, and fibre-bound pools in various sections of the digestive tract, and the routes of loss by absorption and excretion are represented in Fig. 1. This model will form the basis for quantification of tannin metabolism in sheep and goats.

\section{Chemical composition, intake and digestibility of dietary $D M$}

The chemical compositions of pangola, centrosema, desmodium and calliandra fed to sheep and goats are presented in Table 1. Comparisons of intake and digestibilities of DM, OM, NDF, and ADF between sheep and goats fed on the pangola, centrosema, desmodium and calliandra diets are shown in Table 2. Sheep tended to have higher digestibilities of all dietary components, but these differences were not significant $(P>$ $0.05)$. There was no difference between animal species in the proportions $(\mathrm{g} / \mathrm{kg})$ of $\mathrm{OM}$, $\mathrm{NDF}$, and ADF digested in the rumen. There was however an apparent net gain of ADF and to a smaller extent NDF during passage through the hind gut of sheep and goats.

The digestibilities of OM and NDF were not significantly different between diets, but ADF digestibility was significantly $(P<0.05)$ lower in all diets containing legumes. However, significantly $(P<0.05)$ lower proportions of total OM were digested in the rumen of both sheep and goats given diets containing calliandra and desmodium, when compared with the other diets.

\section{Effect of diet on the concentration of ammonia, total and individual volatile fatty acids in the rumen}

Rumen $\mathrm{NH}_{3}$ and VFA concentrations in the rumen of sheep and goats fed on pangola, centrosema, desmodium, and calliandra diets are presented in Table 3. Sheep and goats had similar rumen $\mathrm{NH}_{3}$ concentrations $(P>0.05)$. Rumen VFA concentrations in sheep were significantly higher $(P<0.05)$ than those in goats, but the proportions of individual VFA were not significantly different between sheep and goats. There were small but significant $(P<0.05)$ differences between diets for individual VFA proportions.

\section{Fluid kinetics in the rumen}

The fluid kinetics and mean retention times of ${ }^{51} \mathrm{Cr}$ and ${ }^{103} \mathrm{Ru}$ in the rumen of sheep and goats fed on the treatment diets are shown in Table 4 . Sheep had significantly $(P<0.05)$ larger rumen volumes and tended to have longer water and particulate-matter retention times in the reticulum-rumen than goats $(P<0.05)$ but these measurements were not significantly different between diets.

\section{The digestion of nitrogen and efficiency of rumen microbial protein synthesis}

Mean values for $\mathrm{N}$ intake and $\mathrm{N}$ excretion in sheep and goats given the different diets are presented in Table 5. There were no significant differences between sheep and goats for the digestion and utilization of dietary $\mathbf{N}$. Animals given the desmodium and calliandra diets 


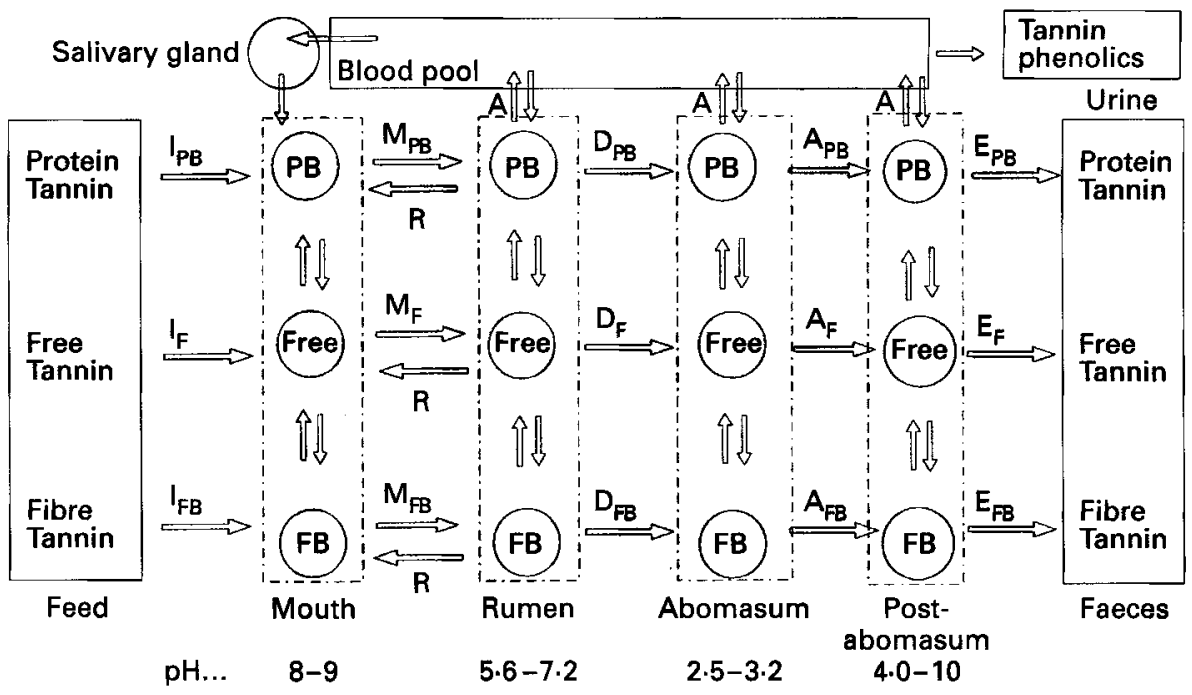

Fig. 1. Model of the passage of condensed tannin (CT) through the digestive tract of ruminants. F, free tannins; $\mathrm{PB}$, protein-bound; FB, fibre-bound; $\mathrm{I}$, intake of $\mathrm{CT}$ fraction $\left(\mathrm{I}_{\mathrm{F}}+\mathrm{I}_{\mathrm{PB}}+\mathrm{I}_{\mathrm{FB}}\right) ; \mathrm{M}$, masticated $\mathrm{CT}$ entering the rumen pool $\left(M_{F}+M_{P B}+M_{F B}\right) ; R$, rumination of $C T$ for re-mastication $\left(R_{F}+R_{P B}+R_{F B}\right) ; D$, ruminal digesta $C T$ flow to abomasum $\left(D_{F}+D_{P B}+D_{F B}\right) ; A$, abomasal digesta $C T$ flow to small intestine $\left(A_{F}+A_{P B}+A_{F B}\right) ; E, C T$ excreted in faeces $\left(E_{\mathrm{F}}+\mathrm{E}_{\mathrm{PB}}+\mathrm{E}_{\mathrm{FB}}\right)$.

had significantly lower $(P<0.05) \mathrm{N}$ digestibilities when compared with those given the centrosema and pangola diets. There were no significant differences between diets for $\mathrm{N}$ retention, expressed either as $\mathrm{mg} \mathrm{N}$ retained $/ \mathrm{kg}^{0.9}$ per $\mathrm{d}$ or as a proportion of $\mathrm{N}$ intake or $\mathrm{N}$ apparently absorbed.

The daily amounts of different fractions of $\mathrm{N}$ leaving the abomasum and their fate in the digestive tract of both sheep and goats fed on pangola grass alone and the mixture diets of pangola and individual legumes are shown in Table 6. Although the abomasal flow of NAN was greater in sheep $(P<0.05)$ than in goats, the proportion of microbial N in NAN flow and the proportion of $\mathbf{N}$ gained across the rumen between animal species were not significantly different. NAN flows $(\mathrm{g} / \mathrm{g}$ N intake) from the abomasum of animals given the desmodium and calliandra diets were significantly higher $(P<0.05)$ than those for pangola and centrosema diets. The apparent degradability of $\mathrm{N}$ from the diets containing $\mathrm{CT}$ (desmodium and calliandra) was significantly $(P<0.05)$ lower than that for centrosema and pangola-grass diets. The efficiency of microbial- $\mathrm{N}$ synthesis, expressed as $\mathrm{g}$ microbial $\mathrm{N} / \mathrm{kg}$ OM apparently digested in the rumen and $\mathrm{g}$ microbial $\mathrm{N} / \mathrm{kg} \mathrm{OM}$ truly digested in the rumen, was not different $(P>0.05)$ between sheep and goats or between diets.

The proportion of $\mathrm{N}$ absorbed in the small intestine was not significantly different between animal species $(P>0.05)$, but animals given the calliandra and desmodium diets absorbed more $\mathrm{N}$ per $\mathrm{kg}$ total $\mathrm{OM}$ digested than those given the centrosema and pangola diets.

\section{The digestion and metabolism of condensed tannins}

Values for the digestibility of free, protein-bound and fibre-bound CT from D. intortum and C. calothyrsus ingested by sheep and goats are shown in Table 7. The intakes of free, protein-bound, and fibre-bound CT were not different between animal species after correction for body size (body weight $\left.(\mathbf{k g})^{0.9}\right)$. Both sheep and goats consumed significantly 


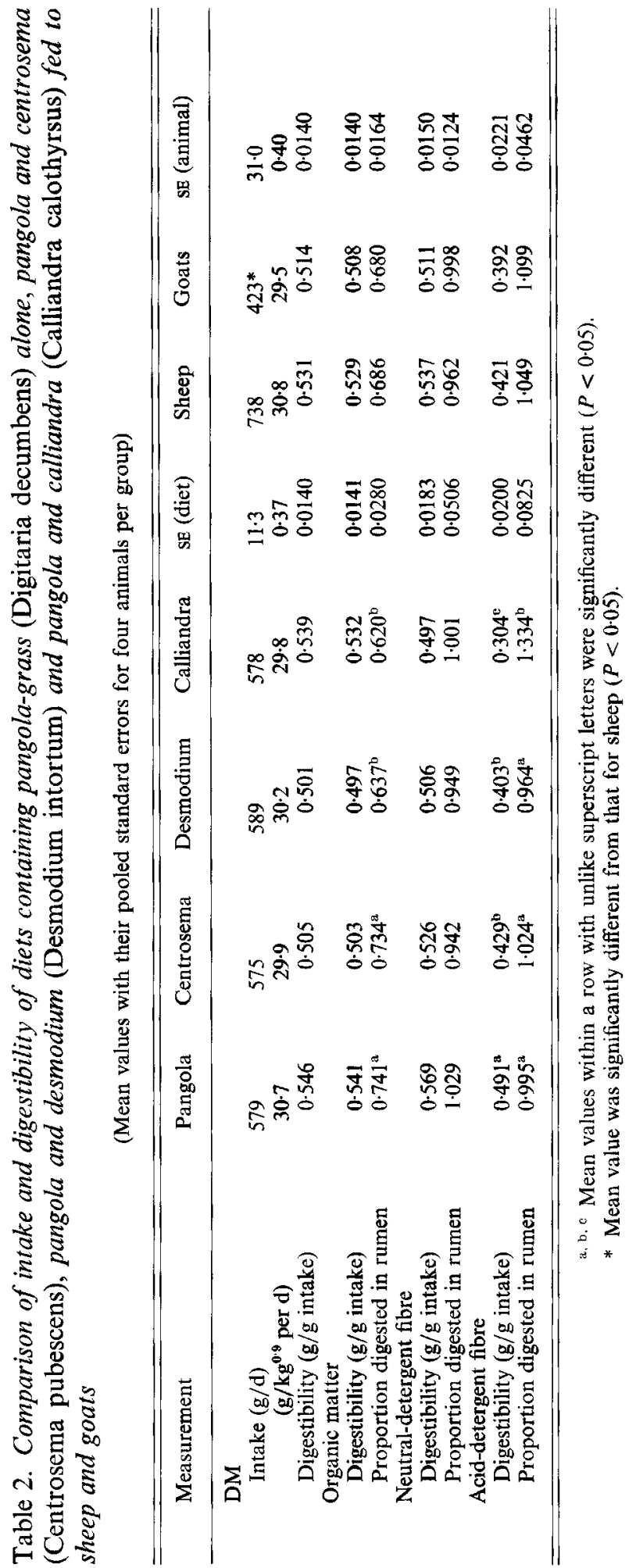


Table 3. Comparison of the concentration of ammonia nitrogen $\left(\mathrm{NH}_{3}-\mathrm{N}\right)$ and total and individual volatile fatty acids (VFA) in the rumen of sheep and goats fed on pangola-grass (Digitaria decumbens) hay alone and mixtures of pangola with Desmodium intortum, Centrosema pubescens, and Calliandra calothyrsus $\dagger$

(Mean values with their pooled standard errors for four animals per group)

\begin{tabular}{|c|c|c|c|c|c|c|c|c|}
\hline & Pangola & Centrosema & Desmodium & Calliandra & SE (diet) & Sheep & Goats & SE (animal) \\
\hline $\mathrm{NH}_{3}-\mathrm{N}(\mathrm{mg} / \mathrm{l})$ & 96 & 101 & 95 & 94 & $6 \cdot 2$ & 98 & 95 & $6 \cdot 4$ \\
\hline Total VFA $(\mathrm{mmol} / \mathrm{l})$ & 76 & 91 & 81 & 81 & $4 \cdot 8$ & 94 & $70^{*}$ & $4 \cdot 4^{*}$ \\
\hline \multicolumn{9}{|l|}{$\begin{array}{l}\text { Individual VFA } \\
(\mathrm{mmol} / \mathrm{mol})\end{array}$} \\
\hline Acetic & $683^{a}$ & $719^{\mathrm{b}}$ & $705^{b}$ & $705^{b}$ & 6.5 & 712 & 694 & 10 \\
\hline Propionic & 207 & 190 & 191 & 195 & $7 \cdot 3$ & 192 & 195 & $6 \cdot 1$ \\
\hline Butyric & $90^{a}$ & $74^{b}$ & $80^{b}$ & $87^{\mathrm{a}}$ & $3 \cdot 6$ & 78 & 88 & $5 \cdot 1$ \\
\hline Others $\ddagger$ & $20^{\mathrm{a}}$ & $17^{\mathrm{a}}$ & $23^{\mathrm{b}}$ & $24^{\mathrm{b}}$ & $1 \cdot 6$ & 19 & 23 & $3 \cdot 1$ \\
\hline
\end{tabular}

a,b Mean values within a row with unlike superscript letters were significantly different $(P<0-05)$.

* Mean value was significantly different from that for sheep $(P<0.05)$.

$\dagger$ For details of diets and procedures, see Table 1 and pp. 516-518.

$\ddagger \mathrm{n}$-Valeric, isovaleric and $\mathrm{n}$-butyric acids.

Table 4. Rumen fluid pool size and mean retention times of ${ }^{51} \mathrm{Cr}$ (fluid) and ${ }^{103} \mathrm{Ru}$ (particulate matter) in the rumen of sheep and goats fed on pangola-grass (Digitaria decumbens) hay alone and mixtures of pangola with Desmodium intortum, Centrosema pubescens, and Calliandra calothyrsus $\dagger$

(Mean values with their pooled standard error for four animals per group)

\begin{tabular}{|c|c|c|c|c|c|c|c|c|}
\hline & Pangola & Centrosema & Desmodium & Calliandra & $\begin{array}{c}\mathbf{S E} \\
\text { (diet) }\end{array}$ & Sheep & Goats & $\begin{array}{c}\mathbf{S E} \\
\text { (animal) }\end{array}$ \\
\hline Rumen volume (litres) & $8 \cdot 9$ & $7 \cdot 5$ & $8 \cdot 7$ & $7 \cdot 6$ & 0.45 & $10 \cdot 4$ & $5 \cdot 9^{*}$ & 0.45 \\
\hline \multicolumn{9}{|l|}{ Mean retention time (h) } \\
\hline${ }^{51} \mathrm{Cr}$ (fluid) & $16 \cdot 9$ & $16 \cdot 7$ & $17 \cdot 2$ & $17 \cdot 0$ & 0.45 & $17 \cdot 6$ & $16 \cdot 3$ & 0.98 \\
\hline${ }^{103} \mathrm{Ru}$ (particles) & $25 \cdot 6$ & $24 \cdot 1$ & $23 \cdot 4$ & $25 \cdot 6$ & $1 \cdot 29$ & $28 \cdot 7$ & $20 \cdot 7^{*}$ & $1 \cdot 76$ \\
\hline
\end{tabular}

* Mean values were significantly different from those for sheep $(P<0-05)$.

$\uparrow$ For details of diets and procedures, see Table 1 and pp. 516-518.

$(P<0.05)$ more total CT from $C$. calothyrsus than from diets containing $D$. intortum. The proportions of total CT intake excreted in urine and faeces, and apparently absorbed, were not significantly $(P>0.05)$ different between either animals or diets.

The apparent absorption or loss of CT entering the small intestines of sheep and goats fed on the desmodium and calliandra diets is presented in Table 8. The amount of total CT leaving the abomasum was significantly higher $(P<0.05)$ for sheep than for goats, but similar when expressed as a proportion of CT intake. The net gain of protein-bound CT was significantly $(P<0.05)$ higher in sheep than in goats, but the apparent CT loss postruminally as a proportion of that leaving the abomasum was not different between animal species. Sheep and goats given the calliandra diet had significantly higher gains of proteinbound CT than those given the desmodium diet, but net losses of free and fibre-bound CT were similar.

The absorption of CT fractions in the post-rumen tract was not statistically different $(P>0.05)$ between species, but animals given calliandra diets lost significantly $(P<0.05)$ 


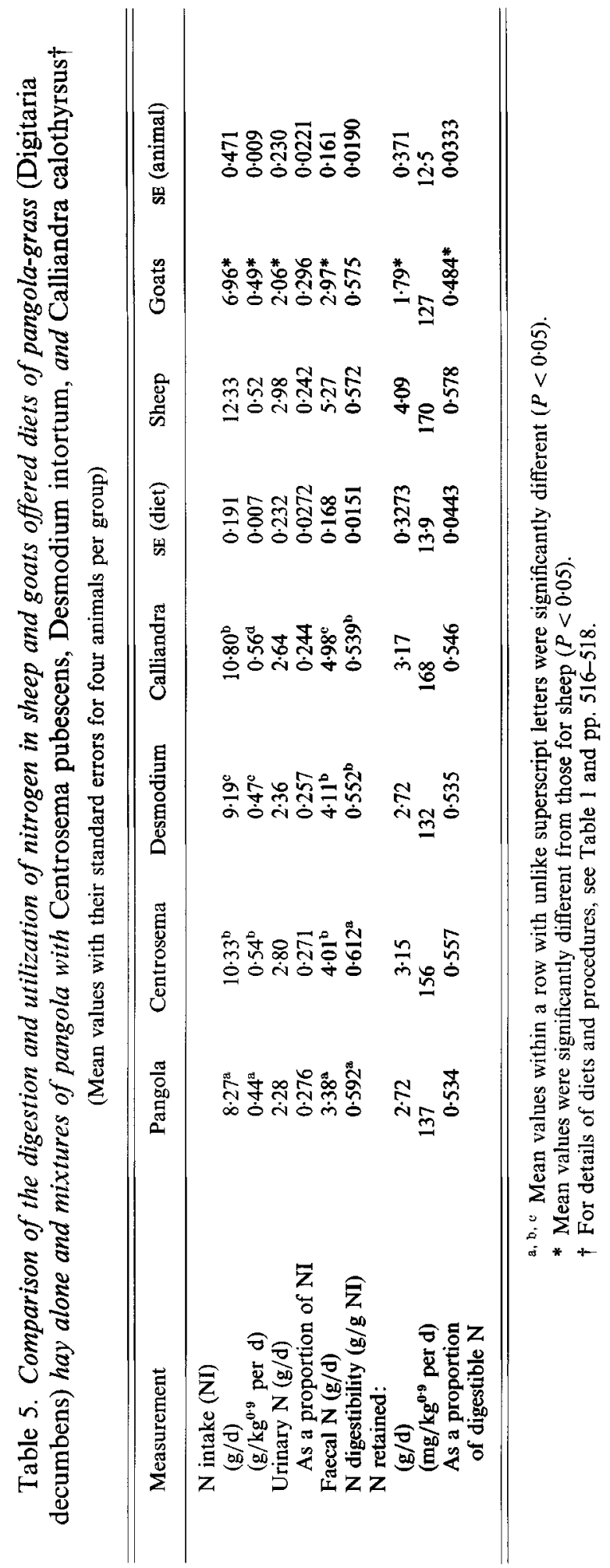


CONDENSED TANNINS AND DIGESTION

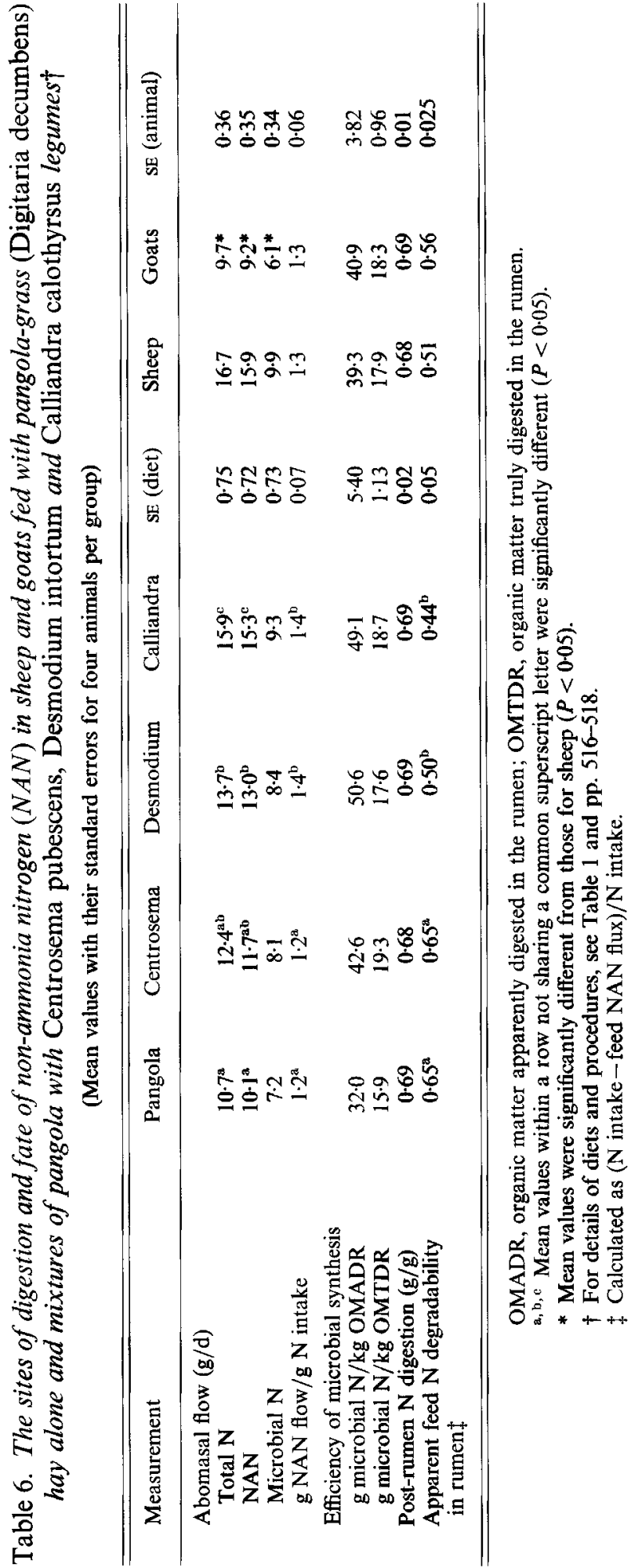


Table 7. The digestion of total condensed tannins $(C T)$ and CT fractions from Desmodium intortum and Calliandra calothyrsus fed to sheep and goats as mixed diets with pangola-grass (Digitaria decumbens) hayt

(Mean values with their pooled standard error for four animals per group)

\begin{tabular}{|c|c|c|c|c|c|c|}
\hline CT & Desmodium & Calliandra & SE (diet) & Sheep & Goats & SE (animal) \\
\hline \multicolumn{7}{|l|}{ Intake (CTI) (g/d) } \\
\hline Free & $1 \cdot 62^{\mathrm{a}}$ & $8 \cdot 30^{\mathrm{b}}$ & 0.219 & $6 \cdot 26$ & $3.67^{*}$ & 0.232 \\
\hline Protein-bound & $2 \cdot 45$ & $2 \cdot 17$ & 0.063 & $2 \cdot 90$ & $1 \cdot 72 *$ & $0 \cdot 108$ \\
\hline Fibre-bound & $1 \cdot 84^{\mathrm{a}}$ & $2 \cdot 80^{\mathrm{b}}$ & 0.097 & $2 \cdot 85$ & $1.79 *$ & 0.102 \\
\hline Total & $5.91^{\mathrm{a}}$ & $13 \cdot 3^{\mathrm{b}}$ & $0 \cdot 323$ & $12 \cdot 0$ & $7 \cdot 19^{*}$ & 0.413 \\
\hline \multicolumn{7}{|l|}{$\mathrm{CT}$ in faeces $(\mathrm{g} / \mathrm{d})$} \\
\hline Free & $0 \cdot 13$ & $0 \cdot 09$ & 0.050 & $0 \cdot 14$ & 0.09 & 0.028 \\
\hline Protein-bound & $0.84^{2}$ & $1 \cdot 54^{\mathrm{b}}$ & 0.084 & 1.48 & $0.89 *$ & 0.062 \\
\hline Fibre-bound & $0.48^{\mathrm{a}}$ & $0.72^{b}$ & 0.032 & 0.84 & $0 \cdot 36^{*}$ & 0.044 \\
\hline Total & $1 \cdot 45^{a}$ & $2 \cdot 35^{\mathrm{b}}$ & $0 \cdot 125$ & $2 \cdot 46$ & $1 \cdot 34^{*}$ & 0.062 \\
\hline Percent of CTI & $24 \cdot 4$ & $17 \cdot 8$ & 1.68 & $22 \cdot 4$ & $19 \cdot 8$ & $1 \cdot 40$ \\
\hline \multicolumn{7}{|l|}{ Apparently absorbed (\%) } \\
\hline Free & $92 \cdot 1$ & $98 \cdot 7$ & 1.86 & $94 \cdot 7$ & $96 \cdot 1$ & 1.76 \\
\hline Protein-bound & $65 \cdot 7^{a}$ & $27 \cdot 8^{\mathrm{b}}$ & $3 \cdot 74$ & $47 \cdot 3$ & $46 \cdot 5$ & $3 \cdot 60$ \\
\hline Fibre-bound & $73 \cdot 5$ & $75 \cdot 6$ & $2 \cdot 30$ & $70 \cdot 7$ & $78 \cdot 3^{*}$ & 1.83 \\
\hline Total & $75 \cdot 6$ & $82 \cdot 2$ & 1.68 & $77 \cdot 6$ & 80.2 & 1.40 \\
\hline \multicolumn{7}{|l|}{ Urine phenolic $(\mathrm{g} / \mathrm{d})$} \\
\hline As total CT & $0 \cdot 29$ & 1.03 & $0 \cdot 147$ & $1 \cdot 19$ & $0.31^{*}$ & $0 \cdot 174$ \\
\hline Percent of CTI & $4 \cdot 7$ & $7 \cdot 9$ & 1.84 & $18 \cdot 7$ & $15 \cdot 7$ & $1 \cdot 54$ \\
\hline \multicolumn{7}{|l|}{ Apparently not recovered } \\
\hline $\mathrm{g} / \mathrm{d}$ & $3 \cdot 4^{\mathrm{a}}$ & $8 \cdot 6^{\mathrm{b}}$ & $0 \cdot 28$ & $7 \cdot 3$ & $4 \cdot 8^{*}$ & 0.35 \\
\hline $\mathrm{g} / \mathrm{kg}^{0-9}$ per $\mathrm{d} \ddagger$ & $0 \cdot 22^{\mathrm{a}}$ & $0 \cdot 51^{\mathrm{b}}$ & $0 \cdot 011$ & 0.348 & $0.38^{*}$ & 0.009 \\
\hline Percent of absorbed CT & $93 \cdot 8$ & $90 \cdot 4$ & $1 \cdot 17$ & 89.2 & $94.9 *$ & $1 \cdot 20$ \\
\hline Percent of CTI & $71 \cdot 0$ & $74 \cdot 2$ & $1-26$ & $69 \cdot 1$ & $76 \cdot 1$ & 1.07 \\
\hline
\end{tabular}

$\mathrm{a}, \mathrm{b}$ Mean values within a row with unlike superscript letters were significantly different $(P<0.05)$.

* Mean values were significantly different from those for sheep $(P<0.05)$.

$\dagger$ For details of diets and procedures, see Table 1 and pp. 516-520.

$\ddagger$ Corrects for differences in body size between sheep and goats.

more free CT post-ruminally than those given the desmodium diet, and significantly less protein-bound and fibre-bound CT.

\section{DISCUSSION}

Intake and digestion of organic matter and cell-wall fractions

All diets provided sufficient $\mathrm{N}$ to meet the minimum requirements for maintenance level $(80 \mathrm{~g}$ crude protein $/ \mathrm{kg}$ ) for sheep and goats (Agricultural Research Council, 1984; National Research Council, 1985). Sheep, which had a larger body size than goats $(30.2 v .18 .5 \mathrm{~kg}$ ), consumed about $43 \%$ more of the DM, OM and cell-wall components than goats (Table 2), however these differences were not significant when adjustments in body size were made between species as suggested by Graham (1972). Many reviews of the comparative VFI of sheep and goats have indicated that when low-quality forages are fed, goats consume about $13 \%$ more than sheep (Tan Chee, 1988). During winter goats ingested more DM and OM than sheep but no differences were found during summer (Domingue et al. 1991) but generally there appears to be little difference between these species over a wide range of diets (Alam, 1985; Reddy et al. 1993; Reddy \& Reddy, 1994). Whilst the site and efficiency of ruminal digestion (as a proportion of total digestion) of $O M$ 
Table 8. Total condensed tannin $(C T)$ and $C T$ fractions entering the small intestines of sheep and goats consuming Desmodium intortum and Calliandra calothyrsus mixed with pangolagrass (Digitaria decumbens) hay $\dagger$

\begin{tabular}{|c|c|c|c|c|c|c|}
\hline $\mathrm{CT}$ & Desmodium & Calliandra & SE (diet) & Sheep & Goats & SE (animal) \\
\hline \multicolumn{7}{|l|}{ Abomasal flow $(\mathrm{g} / \mathrm{d})$} \\
\hline Free & $0 \cdot 52^{\mathrm{a}}$ & $2 \cdot 05^{b}$ & $0 \cdot 154$ & 1.81 & $0.76^{*}$ & $0 \cdot 178$ \\
\hline Protein-bound & 3.49 & $4 \cdot 11$ & $0 \cdot 148$ & $4 \cdot 93$ & $2 \cdot 68^{*}$ & $0 \cdot 134$ \\
\hline Fibre-bound & 0.86 & $0-88$ & 0.055 & $1 \cdot 18$ & $0.55^{*}$ & $0 \cdot 081$ \\
\hline Total CT & $4 \cdot 86^{\mathrm{a}}$ & $7 \cdot 04^{b}$ & $0 \cdot 231$ & $7 \cdot 92$ & $3.98^{*}$ & $0 \cdot 316$ \\
\hline Percent of CT intake (CTI) & $82 \cdot 5^{\mathrm{a}}$ & $51 \cdot 2^{b}$ & 3.27 & 7.06 & $63 \cdot 1^{*}$ & $2 \cdot 12$ \\
\hline \multicolumn{7}{|l|}{$\begin{array}{l}\text { Disappearance in rumen } \\
\text { as percent of CTI }\end{array}$} \\
\hline Free & $69 \cdot 3$ & 76.4 & $4 \cdot 14$ & $68 \cdot 15$ & $77 \cdot 5$ & $3 \cdot 23$ \\
\hline Protein-bound & $-45 \cdot 5^{\mathrm{a}}$ & $-83 \cdot 0^{\mathrm{b}}$ & $4 \cdot 69$ & $-72 \cdot 9$ & $-55 \cdot 6^{*}$ & $4 \cdot 58$ \\
\hline Fibre-bound & $54 \cdot 6$ & $69 \cdot 7$ & $2 \cdot 81$ & $56 \cdot 6$ & $67 \cdot 7^{*}$ & $2 \cdot 57$ \\
\hline \multicolumn{7}{|l|}{$\begin{array}{l}\text { Post-rumen loss as percent of } \\
\text { abomasum flow }\end{array}$} \\
\hline Free & $75 \cdot 4^{\mathrm{a}}$ & $93 \cdot 9^{\mathrm{b}}$ & $3 \cdot 02$ & $86 \cdot 2$ & $83 \cdot 2$ & $4 \cdot 96$ \\
\hline Protein-bound & $76 \cdot 2^{\mathrm{a}}$ & $59 \cdot 5^{b}$ & $2 \cdot 27$ & $70 \cdot 1$ & $65 \cdot 6$ & 1.80 \\
\hline Fibre-bound & $41 \cdot 1^{\mathrm{a}}$ & $15 \cdot 5^{b}$ & $2 \cdot 61$ & $28 \cdot 2$ & $28 \cdot 4$ & $2 \cdot 68$ \\
\hline Total & $69 \cdot 9^{\mathrm{a}}$ & $63 \cdot 3$ & $1 \cdot 38$ & $67 \cdot 8$ & $65 \cdot 4$ & $2 \cdot 14$ \\
\hline \multicolumn{7}{|l|}{ Post-rumen loss as percent CTI } \\
\hline Free & $22 \cdot 6$ & $22 \cdot 3$ & $2 \cdot 31$ & 26.5 & $18 \cdot 5^{*}$ & $2 \cdot 18$ \\
\hline Protein-bound & $111 \cdot 2$ & $110 \cdot 9$ & $4 \cdot 66$ & $119 \cdot 9$ & $102 \cdot 1^{*}$ & 3.68 \\
\hline Fibre-bound & $18 \cdot 9^{\mathrm{a}}$ & $4 \cdot 6^{\mathrm{b}}$ & 1.09 & $14 \cdot 2$ & $9 \cdot 3$ & 1.81 \\
\hline Total CT & $58 \cdot 1^{\mathrm{a}}$ & $33 \cdot 1^{\mathrm{b}}$ & $2 \cdot 46$ & $48 \cdot 2$ & $43 \cdot 0$ & $2 \cdot 61$ \\
\hline
\end{tabular}

a,b Mean values within a row with unlike superscript letters were significantly different $(P<0.05)$.

* Mean values were significantly different from those for sheep $(P<0.05)$.

$\uparrow$ For details of diets and procedures, see Table 1 and pp. 516-520.

(0.686 and 0.680 for sheep and goats respectively) was comparable with that found in other studies (Chapman, 1986), the digestion of the fibre fractions (NDF and ADF) in the rumen appeared to be overestimated. This may be associated with the formation of 'artifact' fibre as a result of fibre-tannin interactions, and will be discussed in more detail later.

The calliandra and desmodium diets contained relatively low CT concentrations (23 and $10 \mathrm{~g} / \mathrm{kg} \mathrm{DM}$ respectively) and total OM digestibility was little different to that of non-CTcontaining diets. However, the proportions of OM digested in the rumen from these diets were lower $(0.62$ and 0.64$)$ than that for the pangola and centrosema diets $(0.74$ and 0.73$)$. Barry \& Manley (1984) have reported a depression in the digestibility of both carbohydrate and $\mathrm{N}$ in the rumen for sheep given Lotus pedunculatus diets containing $100 \mathrm{~g} \mathrm{CT} / \mathrm{kg}$, and it has been proposed that lotus diets containing greater than $40 \mathrm{~g} \mathrm{CT} / \mathrm{kg}$ have detrimental effects on ruminant digestion (Waghorn et al. 1987). Similar observations have been made when mulga (Acacia aneura) of varying CT content (Goodchild (1989) approximately $30 \mathrm{~g}$ CT/kg OM; Pritchard et al. (1992) 50-75 g CT/kg DM) has been fed to sheep. Although these CT concentrations were apparently much higher than those found in the present study, direct comparison is not possible because the techniques used for CT determination were different for all studies. For example, both Barry et al. (1986) and Goodchild (1989) used the vanillin- $\mathrm{HCl}$ method and catechin as a standard, and CT contents estimated for our diets by this method (see Table 1) would have been either higher (calliandra) or lower (desmodium) than those found when butanol- $\mathrm{HCl}$ was used. It is therefore not possible at present to predict from information in the literature the levels of CT in feeds which would 
result in depression of diet digestibility, and such predictions will only be possible when a standard (and specific) methodology for CT analysis is adopted for use in nutritional laboratories.

Both sheep and goats given calliandra diets digested ADF with a much lower efficiency $(0 \cdot 30)$ than those given the other diets $(0 \cdot 40-0 \cdot 49)$. It may be calculated from Table 2 that whilst a net loss (digestion) of ADF occurred in the rumen (39\%), there was an apparent net gain of ADF (15\%) during passage through the lower digestive tract. When compared with values from sheep and goats given pangola grass, ADF digestibility in the rumen was 0.47 and there was a further loss of ADF $(0.04)$ in the post-rumen tract. Similar observations of ADF gain in the lower intestinal tract have been reported in other experiments where high-CT diets have been fed to sheep (Goodchild, 1989; Ahn, 1990). It is proposed that during passage through the gastrointestinal tract, free CT may complex with fibre and protein components thereby increasing the apparent ADF fraction in faeces. Carre \& Brillouet (1986) and Van Soest et al. (1987) have proposed that tannin complexes with protein and fibre components remain in the ADF fraction, thereby increasing the apparent lignin content.

\section{The effect of condensed tannins on ammonia and volatile fatty acid concentrations in the} rumen of sheep and goats

In the present study, CT from calliandra and desmodium diets complexed with proteins (dietary and/or endogenous) as demonstrated by increased flows of protein-bound CT ( 50 and $83 \%$ respectively) to the small intestine (Table 8). However rumen $\mathrm{NH}_{3}$ concentrations remained high (90-100 $\mathrm{mg} \mathrm{N} / \mathrm{l})$ and were not affected by dietary CT intake. Studies with both $L$. pedunculatus and $C$. calothyrsus have found that high levels of dietary CT significantly decrease rumen $\mathrm{NH}_{3}$ concentrations (Waghorn et al. 1987; Ahn, 1990), and clearly demonstrate the protective effect of tannins on rumen degradation of proteins. In the present experiment where desmodium and calliandra diets provided $30 \%$ dietary intake, CT intakes were sufficient to protect protein from microbial degradation without affecting microbial $\mathrm{N}$ synthesis (Table 6), dietary OM digestibility, VFA concentrations or their proportions, or the kinetics of liquid and solid digesta movement in the rumen.

\section{The effect of condensed tannins on the digestion and utilization of nitrogenous constituents by sheep and goats}

Results shown in Table 5 indicated that despite differences in $\mathrm{N}$ intake among animals ( $P$ $<0.05)$ and diets $(P<0.05)$, there was no effect on routes of $\mathrm{N}$ excretion in urine and faeces. Major differences were, however, found between diets, and those which contained CT (desmodium and calliandra) resulted in higher faecal $\mathrm{N}$ excretion and lower $\mathrm{N}$ digestibilities than non-CT-containing diets (pangola and centrosema). Higher faecal- $\mathrm{N}$ excretion on CT diets suggests that significant quantities of protein complexed with CT may have passed unchanged through the digestive tract. It would seem that CT-containing diets may increase the flow of $\mathbf{N}$ to the small intestine and, providing the $\mathrm{CT}$-protein complex is dissociated in the lower tract (small intestines, caecum and large intestines), such diets will result in an improved $\mathrm{N}$ absorption and retention. However where the complex is only partially dissociated, the increased flow may pass undigested through the lower tract and be completely lost as excretion in faeces (Thomson et al. 1971; Nastis \& Malechek, 1981; Nuñez-Hernandez et al. 1989).

In the present experiment, 50 and $56 \%$ of dietary $\mathrm{N}$ passed apparently undigested through the rumen of sheep and goats given diets containing desmodium and calliandra respectively, whereas only $35 \%$ apparently escaped digestion in diets containing centrosema and pangola grass only. These results support the view that $\mathrm{CT}$ protects plant 
protein from rumen digestion. Since there were no significant differences in post-rumen $\mathrm{N}$ digestion on any diet $(0 \cdot 68-0.69$, Table 6$)$, it is clear that the observed increase in faecal $N$ excretion was the result of an increased total flow of $\mathrm{N}$ and not due to a decreased digestion and absorption of these proteins in the lower digestive tract. Since the values found for post-rumen $\mathbf{N}$ digestibility are similar to those reported by the Agricultural Research Council (1984), it would appear that all CT-protein complexes formed during passage through the rumen are completely dissociated post-ruminally. Despite the observed protection of dietary proteins from ruminal digestion, there were no major effects of dietary CT on overall dietary $\mathrm{N}$ or OM digestion and utilization at the levels of CT provided.

\section{Condensed tannin metabolism in the whole animal}

The metabolism of condensed tannin in the digestive tract of sheep and goats. In the present study it has been assumed that CT in plants exist in three major forms (free, protein-bound and fibre-bound), with an interchange taking place between the forms during metabolism. It is also assumed that only free CT may undergo degradation or absorption, since the protein and fibre complexes are too large to be absorbed or metabolized. The present study investigated CT metabolism in both the rumen and lower digestive tract by following the movement of CT between these different forms, with the aim of developing a model of CT metabolism in ruminants (Fig. 1). Goodchild (1989) has reported total CT losses of 56 and $35 \%$ from the rumen of sheep fed on leucaena and mulga respectively. Ahn (1990) has found CT losses from the rumen of 24 and $73 \%$ in sheep fed on calliandra diets. In the present study the metabolism of dietary CT was also evaluated as total CT. For example, CT from the desmodium diet showed a $76 \%$ net loss during transit through the digestive tract with $24 \%$ of this loss actually occurring in the rumen. Corresponding values for calliandra were $82 \%$ loss during transit from which only $57 \%$ was lost in the rumen (Table 7). Whilst the total loss of this CT was similar, the site of digestion and/or absorption appeared to be different. This difference may be related to the forms in which tannins enter the rumen and these details are described in the following section.

Metabolism of free tannins in sheep and goats. There were no significant differences between sheep and goats in the metabolism of free CT. From the values shown in Tables 7 and 8 it may be demonstrated that 69 and $76 \%$ of the free CT from desmodium and calliandra respectively were lost after entering the rumen. This free-CT loss may be by binding to proteins or 'fibre', by metabolism in the rumen, by microbial fermentation or by absorption across the rumen wall. It may be calculated from the values given in Tables 7 and 8 that $68 \%(1.04 \mathrm{~g} / \mathrm{d})$ of the free CT entering the rumen from dietary desmodium was lost from this pool; this represents $74 \%$ of the total free-tannin loss over the whole digestive tract. Corresponding values for calliandra were $75 \%(6.23 \mathrm{~g} / \mathrm{d})$ lost by similar routes in the rumen, and $76 \%$ of total free-tannin loss during digestion. These higher losses of free tannin from calliandra may be related to the higher concentrations of free tannins found in these plant tissues. For both diets there was a net gain of free CT to a protein fraction (complexation) and a net loss from fibre-bound CT (dissociation) with passage through the rumen.

On both diets little free CT entered the small intestine from the abomasum but significant amounts of free CT were generated from both protein and fibre fractions during passage to faeces. It is likely that free CT were released largely in the duodenum by the action of detergents in the biliary secretions. The post-abomasum tract was the major site of free tannin degradation and/or absorption for desmodium from which $77 \%(3.42 \mathrm{~g} / \mathrm{d})$ of the total free-CT absorption occurred. Corresponding values for calliandra were $57 \%$ $(6.23 \mathrm{~g} / \mathrm{d})$ of the total free-CT absorption.

Metabolism of protein-bound tannin in sheep and goats. Plant tannins may be bound to 
a variety of proteins during metabolism. These proteins may be derived from saliva during mastication, and from plant protein from cell rupture and endogenous proteins. Sheep had significantly higher gains $(73 \%)$ of protein-bound CT across the rumen when compared with goats $(56 \%)$. The reasons for this difference are not clear. There were net gains of protein-bound CT of 46 and $83 \%$ across the rumen for desmodium and calliandra respectively, supporting the view that tannin-protein complexes are formed during passage from the mouth to the small intestine. Presumably the higher amount of protein-bound CT for calliandra was associated with the greater flow of undegraded protein observed in animals fed on this diet (Table 6). The relatively low amounts of protein-bound CT found in faeces suggests that a substantial proportion of this fraction was dissociated and absorbed and/or metabolized during the passage in the lower digestive tract. There is no evidence from the present study to suggest that protein-tannin complexes formed from desmodium and calliandra CT are resistant to digestion in the lower gastrointestinal tract.

Metabolism of fibre-bound tannins in sheep and goats. The binding of CT to plant fibre (cell walls) presumably occurs during cell disruption and the site of binding may actually be to proteins contained within the matrix of the cell wall. CT thus bound may inhibit plant cell-wall digestion and be characterized as lignin during chemical analysis of cell walls (McArthur, 1987; Van Soest et al. 1987; Rebole et al. 1990; Rittner \& Reed, 1992). In the present experiment fibre-bound CT levels were found to be higher in calliandra than in desmodium and these higher levels were associated with the depressed digestibility of ADF in the calliandra diets (Table 2). For both diets there was a progressive decrease in fibrebound CT as plant material moved from the rumen to faeces. This change may represent either the dissociation of CT from cell-wall constituents or increasing polymerization of existing CT with decreasing colour reactivity. Generally there were few differences between sheep and goats for the digestion of fibre-bound CT. New methods are being developed which distinguish tannin from lignin bound to fibre (Van Soest et al. 1987; Rebole et al. 1990; Rittner \& Reed, 1992) and these methods will facilitate a greater understanding of the significance of fibre-bound CT in forage and tree legumes.

The fate of apparently absorbed tannins. The apparent disappearance of free CT from the digestive tract may be explained by either degradation or absorption. Although there have been no published studies of ruminal metabolism of CT, there is evidence that simple phenolic compounds related to the flavanoid family $((+)$-catechin) may be extensively degraded by rat-caecal microflora (Shaw \& Griffiths, 1980; Groenewoud \& Hunt, 1984, 1986). The mechanisms (enzymes) involved in this process are, as yet, still unknown (Groenewoud \& Hunt, 1986; Deschamps, 1989). In the present study CT were not detected in urine, and indirect evidence for the absorption of CT was the increased excretion of phenolic compounds in urine when CT intakes were increased (Table 7). It is not possible from the results obtained to determine the proportion of CT absorbed which was excreted as phenolic end-products in urine, nor could any other routes of CT loss from the digestive tract be quantified.

Modelling condensed tannin metabolism. The data collected in the present study have been collated and fitted to a schematic model (Fig. 1) to describe the quantitative exchange during metabolism of CT between its three major different forms (free, protein-bound and fibre-bound), and interchange between the forms in different parts of the digestive tract of sheep and goats (Fig. 2). Mean values obtained from sheep and goats fed on desmodium and calliandra diets were used (Tables 7 and 8 ). Sheep consuming a daily diet containing $6 \cdot 26,2.90$ and $2 \cdot 85 \mathrm{~g}$ of free, protein-bound and fibre-bound CT respectively would have the following CT metabolism (comparative values for goats in Fig. 2 are in parentheses). Although the studies on CT metabolism during mastication are not presented in the present paper, experimental work carried out previously has indicated that substantial amounts of 


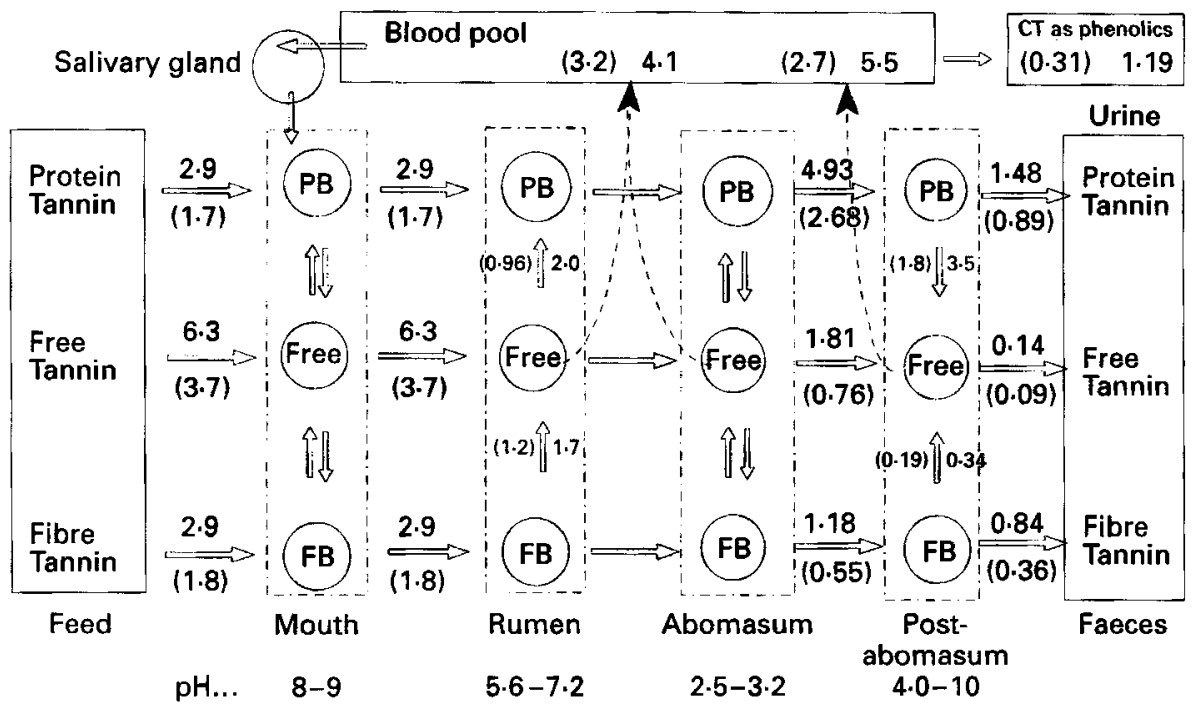

Fig. 2. Model describing the exchanges $(\mathrm{g} / \mathrm{d})$ of condensed tannin $(\mathrm{CT})$ between free, protein-bound (PB) and fibre-bound (FB) tannin pools in sheep and goats (values for goats are given in parentheses).

free CT are released during mastication hence the chance of interacting with the protein and fibrous fractions of plant tissue. CT-fraction measurements that were obtained from abomasum digesta flowing to the small intestine allowed us to suggest that in sheep at the rumen level, $2.03 \mathrm{~g}$ of the $6.26 \mathrm{~g}$ free CT fraction (which had already initiated its binding action with protein and fibre plant tissue) would have bound to plant protein molecules increasing the tannin-protein fraction from 2.90 to $4.93 \mathrm{~g}$ across the rumen (comparative values for goats are in parentheses; Fig. 2). At the rumen level, $1.81 \mathrm{~g}$ free tannin that was neither metabolized nor bound to any other fraction flowed to the free fraction abomasum compartment. Although this is not yet clear, it is speculated that the free CT loss of $2.42 \mathrm{~g}$ in sheep may be digested and/or metabolized by rumen micro-organisms to non-phenolic compounds and be excreted (undetected colorimetrically) in urine. Another possible route of free-CT loss is by binding to the fibre fraction and passage to the abomasum $(1.18 \mathrm{~g}$ was detected by colorimetric methods) therefore creating $4.09 \mathrm{~g}$ of artifact lignin (comparative values for goats are in parentheses, Fig. 2).

The combined action of both high $\mathrm{pH}$ and the detergent action of bile salts in the duodenum and small intestine caused the disruption of tannin-protein complexes from which only $1.48 \mathrm{~g}$ was detected in faeces. Some of the remaining $3.45 \mathrm{~g}$ CT released after the abomasum would have combined with the fibre fraction $(0.34 \mathrm{~g} \mathrm{CT})$, leaving a total of $5.46 \mathrm{~g}$ CT which must have been digested, absorbed, or metabolized by caecal microorganisms and excreted as non-phenolic conjugates (comparative values are represented in parentheses, Fig. 2). These calculations support the view that a substantial amount of CT may bind to the fibre fraction and result in the observed increase in 'artifact' lignin and an apparent indigestibility of dietary $\mathrm{ADF}$.

The authors wish to acknowledge the assistance of the staff at Mount Cotton Research Farm for the management of the experimental animals, and to Linda Cafe and Michael Nielsen for technical assistance. 


\section{REFERENCES}

Ahn, J. H. (1990). Quality assessment of tropical browse legumes: tannin content and nitrogen degradability. PhD Thesis, University of Queensland, St. Lucia, Australia.

Agricultural Research Council (1984). The nutrient requirements of ruminant livestock. In Technical Review ARC Working Party, Suppl. 1. Farnham Royal: Commonwealth Agricultural Bureaux.

Alam, M. R. (1985). Forage utilization by kids and lambs. PhD Thesis, University of Canterbury (Lincoln College), New Zealand.

Barry, T. N. \& Duncan, S. J. (1984). The role of condensed tannins in the nutritional value of Lotus pedunculatus for sheep. 1. Voluntary intake. British Journal of Nutrition 51, 485-491.

Barry, T. N. \& Manley, T. R. (1984). The role of condensed tannins in the nutritional value of Lotus pedunculatus for sheep. 2. Quantitative digestion of carbohydrates and proteins. British Journal of Nutrition 51, $493-504$.

Barry, T. N., Manley, T. R. \& Duncan, S. J. (1986). The role of condensed tannins in the nutritional value of Lotus pedunculatus for sheep. 4 . Sites of carbohydrate and protein digestion as influenced by dietary reactive tannin concentration. British Journal of Nutrition 55, 123-137.

Bate-Smith, E. C. (1981). Astringent tannins of leaves of Geranium species. Phytochemistry 20, $211-216$.

Carre, B. \& Brillouet, J. M. (1986). Yield and composition of cell wall residues isolated from various feedstuffs used for non-ruminant farm animals. Journal of the Science of Food and Agriculture 37, 341-351.

Chapman, P. G. (1986). Protein degradation in the rumen of sheep fed pangola grass and siratro hay. Master of Agricultural Science Thesis, University of Queensland, St. Lucia, Australia.

Deschamps, A. M. (1989). Microbial degradation of tannins and related compounds. In Plant Cell Wall Polymers Biogenesis and Biodegradation, pp. 559-566 [N. G. Lewis and M. G. Paice, editors]. Washington, DC: American Chemical Society.

Domingue, F. B. M., Dellow, D. W. \& Barry, T. N. (1991). Comparative digestion in deer, goats and sheep. New Zealand Journal of Agricultural Research 34, 45-53.

Downes, A. M. \& McDonald, I. W. (1964). The chromium-51 complex of ethylenediamine tetracetic acid as a soluble rumen marker. British Journal of Nutrition 18, 153-162.

Elliott, R. \& Armstrong, D. G. (1982). The effect of urea plus sodium sulphate on microbial protein production in the rumen of sheep given high alkali-treated barley straw. Journal of Agricultural Science, Cambridge 99 , $51-60$.

Faichney, G. J. (1975a). The use of markers to partition digestion within gastro-intestinal tract of ruminants. In Digestion and Metabolism in the Ruminant, pp. 277-291 [A. C. 1. Warner and I. W. McDonald, editors]. Armidale, NSW: University of New England Publishing Unit.

Faichney, G. J. (1975b). The effect of formaldehyde treatment of a concentrate diet on the passage of solute and particle markers through the gastrointestinal tract of sheep. Australian Journal of Agricultural Research 13, 319-327.

Faichney, G. J. (1980). Measurements in sheep of the quantity and composition of rumen digesta and of the fractional outflow rates of digesta constituents. Australian Journal of Agricultural Research 31, 1129-1137.

Goering, H. K. \& Van Soest, P. J. (1970). Forage Fibre Analyses. Apparatus, Reagent, Procedures, and Some Applications. Agriculture Handbook no. 379. Washington, DC: Agricultural Research Service/US Department of Agriculture.

Goodchild, A. V. (1989). Use of leguminous browse foliage to supplement low quality roughages for ruminants. PhD Thesis, University of Queensland, St. Lucia, Australia.

Graham, N. McC. (1972). Units of metabolic body size for comparisons among adult sheep and cattle. Proceedings of the Australian Society of Animal Production 9, 352.

Groenewoud, G. \& Hunt, H. K. L. (1984). The microbial metabolism of (+)-catechin to two novel diarylpropan2-ol metabolites in vitro. Xenobiotica 14, 711-717.

Groenewoud, G. \& Hunt, H. K. L. (1986). The microbial metabolism of condensed (+)-catechins by rat-caecal microflora. Xenobiotica 16, 99-107.

Jones, W. T. \& Mangan, J. L. (1977). Complexes of the condensed tannins of sainfoin (Onobrychis viciifolia Scop.) with Fraction 1 leaf protein and with submaxillar mucoprotein, and their reversal by polyethylene glycol and pH. Journal of the Science of Food and Agriculture 28, 126-136.

McArthur, C. (1987). Histology of neutral detergent fibre from a tannin-rich foliage. In Herbivore Nutrition Research, pp. 43-44 [M. Rose, editor]. Brisbane: Australian Society of Animal Production.

Nastis, A. S. \& Malechek, J. C. (1981). Digestion and utilization of nutrients in oak browse by goats. Journal of Animal Science 53, 283-290.

National Research Council (1985). Nutrient Requirements of Domestic Animals. Nutrient Requirements of Sheep, 6th ed. Washington, DC: NRC, National Academy Press.

Norton, B. W., Peiris, H. \& Elliott, R. (1994). Fermentation patterns and diet utilization by cattle, sheep and goats given grain or molasses based rations. Proceedings of the Australian Society of Animal Production 20, $182-185$.

Nuñez-Hernandez, G., Holechek, J. L., Wallace, J. D., Galyean, M. L., Ackimtemb, R. \& Cardenas, M. (1989). Influence of native shrubs on nutritional status of goats: nitrogen retention. Journal of Range Management $\mathbf{4 2}$, $228-232$.

Perez-Maldonado, R. A. (1994). The chemical nature and biological activity of tannins in forage legumes fed to sheep and goats. PhD Thesis, University of Queensland, Australia. 
Pritchard, D. A., Martin, P. R. \& Rourke, P. K. (1992). The role of condensed tannins in the nutritional value of Mulga (Acacia aneura) for sheep. Australian Journal of Agricultural Research 43, 1739-1746.

Purchas, R. W. \& Keogh, R. G. (1984). Fatness of lambs grazed on grassland maku lotus and grasslands huia white clover. Proceedings of the New Zealand Society of Animal Production 44, 219-221.

Rebole, A., Alvira, P. \& Gonzales, G. (1990). Relationship among compositional data of fibrous by-products as determined by two different extractions in the detergent system of analysis. Influence on the prediction of the digestibility. Journal of the Science of Food and Agriculture 53, 15-22.

Reddy, M. R., Chandrasekharaja, H., Govindajah, T. \& Reddy, G. V. N. (1993). Effect of physical processing on the nutritive value of sugar cane bagasse in goats and sheep. Small Ruminant Research 10, 25-31.

Reddy, G. V. N. \& Reddy, M. R. (1994). Effect of processing of Heteropogon contortus hay on nutrient utilization in goats and sheep. Small Ruminant Research 13, 15-19.

Rittner, U.\& Reed, J. D. (1992). Phenolics and in-vitro degradability of protein and fibre in West African browse. Journal of the Science of Food and Agriculture 58, 21-28.

Shaw, I. C. \& Griffiths, L. A. (1980). Identification of the major biliary metabolite of (+)-catechin in the rat. Xenobiotica 10, 905-911.

Singleton, V. L. \& Rossi, J. A. Jr (1965). Colorimetry of total phenolics with phosphomolybdic-phosphotungstic acid reagents. American Journal of Enology and Viticulture 16, 143-144.

Tan Chee, M. (1988). Utilization of low quality roughages by goats and sheep. PhD Thesis, University of Canterbury (Lincoln College), New Zealand.

Tan, T. N., Weston, R. H. \& Hogan, J. P. (1971). Use of ${ }^{109}$ Ru-labelled tris (1,10-phenanthroline) ruthenium (1I) chloride as a marker in digestion studies with sheep. International Journal of Applied Radiation and Isotopes $\mathbf{2 2}$, 301-308.

Terrill, T. H., Rowan, A. M., Douglas, G. B. \& Barry, T. N. (1992). Determination of extractable and bound condensed tannin concentration in forage plants, protein concentrate meals and cereal grains. Journal of the Science of Food and Agriculture 58, 321-329.

Terrill, T. H., Waghorn, G. C., Woolley, D. J., McNabb, W. C. \& Barry, T. N. (1994). Assay and digestion of ${ }^{14}$ Clabelled condensed tannins in the gastrointestinal tract of sheep. British Journal of Nutrition 72, 467-477.

Thomson, D. E., Beever, D. E., Harrison, D. G., Hill, I. W. \& Osbourn, D. F. (1971). The digestion of dried lucerne (Medicago sativa L.) and dried sainfoin (Onobrychis viciifolia Scop.) by sheep. Proceedings of the Nutrition Society 30, 14A.

Van Soest, P. J., Conklin, N. L. \& Horvath, P. J. (1987). Tannins in foods and feeds. In Cornell Nutrition Conference for Feed Manufacturers Proceedings, pp. 115-122. Ithaca, NY: Cornell University.

Waghorn, G. C. (1990). Effect of condensed tannin on protein digestion and nutritive value of fresh herbage. Proceedings of the Australian Society of Animal Production 18, 412-415.

Waghorn, G. C., Jones, W. T. \& Shelton, I. D. (1987). The nutritive value of Lotus corniculatus L. containing low and medium concentrations of condensed tannins for sheep. Proceedings of the New Zealand Society of Animal Production 47, 75-80. 